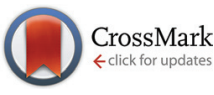

Cite this: Org. Chem. Front., 2015, 2, 968

\title{
Asymmetric aza-Henry reaction to provide oxindoles with quaternary carbon stereocenter catalyzed by a metal-templated chiral Brønsted base $\uparrow$
}

\author{
Ying $\mathrm{Hu}^{a}{ }^{\mathrm{a}}$ Zijun Zhou, ${ }^{\mathrm{a}}$ Lei Gong ${ }^{\star a}$ and Eric Meggers ${ }^{\star a, b}$
}

\begin{abstract}
An asymmetric aza-Henry reaction between isatin-derived ketimines and aryl nitromethanes is catalyzed by an inert octahedral chiral-at-metal iridium(III) complex which serves as a chiral Brønsted base. Initially, a kinetically favored diastereomer is formed with high diastereoselectivity and excellent enantioselectivity, and can be epimerized efficiently under base catalysis into the thermodynamically favored diastereomer. The work underscores the potential of our metal-templated approach for the design of high performance asymmetric catalysts.
\end{abstract}

Received 17th April 2015,

Accepted 11th June 2015

DOI: $10.1039 / c 5 q 000132 c$

rsc.li/frontiers-organic

The aza-Henry (nitro-Mannich) reaction, namely the addition of nitronate nucleophiles to imine electrophiles, is a highly useful $\mathrm{C}-\mathrm{C}$ bond forming reaction and provides straightforward access to a variety of nitrogen-containing chiral building blocks and scaffolds. ${ }^{1}$ The significant $\alpha-\mathrm{C}-\mathrm{H}$ acidity of nitroalkanes in combination with the high nucleophilicity of the resulting nitronates offers attractive opportunities to develop asymmetric versions of these reactions through chiral Brønsted base catalysis. ${ }^{2}$ Furthermore, the ability to increase the reactivity of imines through hydrogen bond interactions provides an additional handle for lowering the energy of the transition state and for controlling the asymmetric induction by means of bifunctional catalysis. ${ }^{2,3}$

Our group recently introduced a new class of bifunctional chiral Brønsted base catalysts based on chiral octahedral iridium(III) complexes. In these metal-templated catalysts, the metal fulfills a purely structural role and constitutes the exclusive source of chirality (metal-centered chirality), ${ }^{4-8}$ while the actual catalysis is mediated through carefully arranged functional groups within the organic ligand sphere. Based on this concept, we developed iridium(III) 3-aminopyrazolate complexes as low-loading catalysts for sulfa-Michael (down to $0.02 \mathrm{~mol} \%$ catalyst loading) and aza-Henry reactions (down to

\footnotetext{
${ }^{a}$ Key Laboratory for Chemical Biology of Fujian Province and Department of Chemical Biology, College of Chemistry and Chemical Engineering, Xiamen University, Xiamen 361005, People's Republic of China. E-mail: gongl@xmu.edu.cn, meggers@chemie.uni-marburg.de

${ }^{b}$ Fachbereich Chemie, Philipps-Universität Marburg, Hans-Meerwein-Strasse, 35043 Marburg, Germany

$\dagger$ Electronic supplementary information (ESI) available. CCDC 1060112 and 1060102. For ESI and crystallographic data in CIF or other electronic format see DOI: $10.1039 / \mathrm{c} 5 q 000132 \mathrm{c}$
}

$0.25 \mathrm{~mol} \%$ catalyst loading). ${ }^{9,10}$ We believe that the stereochemical complexity of the octahedral scaffold provided us with an advantage with respect to the proper arrangement of functional groups and the intrinsic rigidity facilitated a reduced entropic penalty when reaching the transition state. To further investigate the merit of such metal-templated chiral Brønsted base catalysts in asymmetric catalysis, we herein expand the scope of the previously investigated aza-Henry reaction of benzaldehyde derived imines to isatin ketimine substrates. ${ }^{11,12}$ Isatin-derived ketimines are highly attractive substrates since they are converted to 2-oxindoles with a quaternary stereocenter in 3-position which constitutes an important chiral structural motif for bioactive natural products and drug candidates (Fig. 1). ${ }^{13,14} \mathrm{~A}$ few asymmetric catalysts have been reported recently for the aza-Henry reaction with isatin-derived ketimines, such as quinine-derived bifunctional organocatalysts developed by Zhou and coworkers, ${ }^{12 a}$ bis(imidazolidine)pyridine-nickel(II) complexes by Arai's group, ${ }^{12 b}$ bisoxazoline copper(II) complexes by Pedro and coworkers, ${ }^{12 c}$ and a bifunctional guanidine-amide catalyst by Feng's group. ${ }^{12 d}$ However, despite providing excellent results, these reports are limited to nitromethane, nitroethane, and nitropropane, whereas the here presented study deals with the substrate class of aryl nitromethanes.

We started our study with the aza-Henry reaction between the isatin $N$-Boc ketimine 1a and (nitromethyl)benzene 2a (Fig. 2, top). Under optimized reaction conditions, at $-30{ }^{\circ} \mathrm{C}$ using $i \mathrm{Pr}_{2} \mathrm{O}$ as the solvent (see ESI $\dagger$ for a comparison with other solvents), we found that a catalyst loading of merely $0.5 \mathrm{~mol} \%$ led to a complete conversion to the C-C-bond formation product 3a after 24 hours. HPLC analysis on chiral stationary phase revealed that the crude compound was 


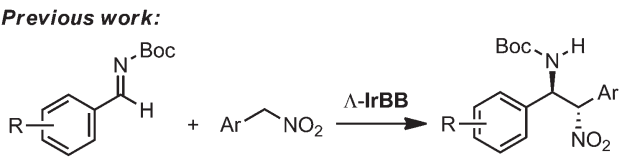

This study:

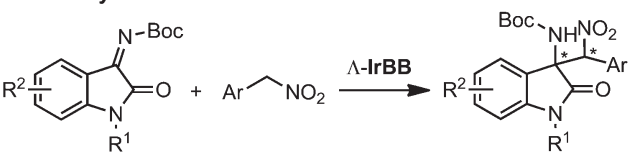

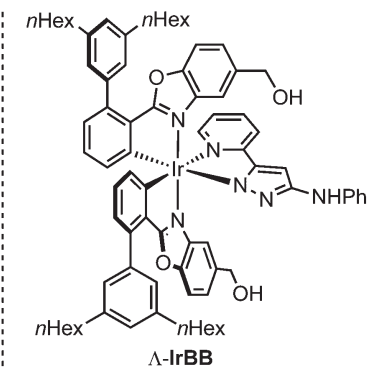

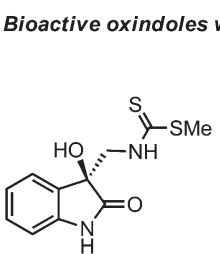

(S)-(-)-dioxibrassinin

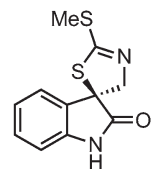

$(S)-(-)-$ spirobrassinin<smiles>CCOC(CC)CN1C(=O)[C@](NC(=O)Nc2ccc([N+](=O)[O-])cc2)(C(=O)Nc2ccc(C)cc2)c2ccccc21</smiles>

cholecyctokinin-B/gastrin receptor antagoinist

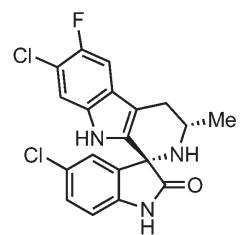

antimalarial agent

Fig. 1 Previous work and this study regarding asymmetric aza-Henry reactions catalyzed by a metal-templated Brønsted base together with a selection of bioactive oxindoles with a quaternary stereocenter in the 3-position.
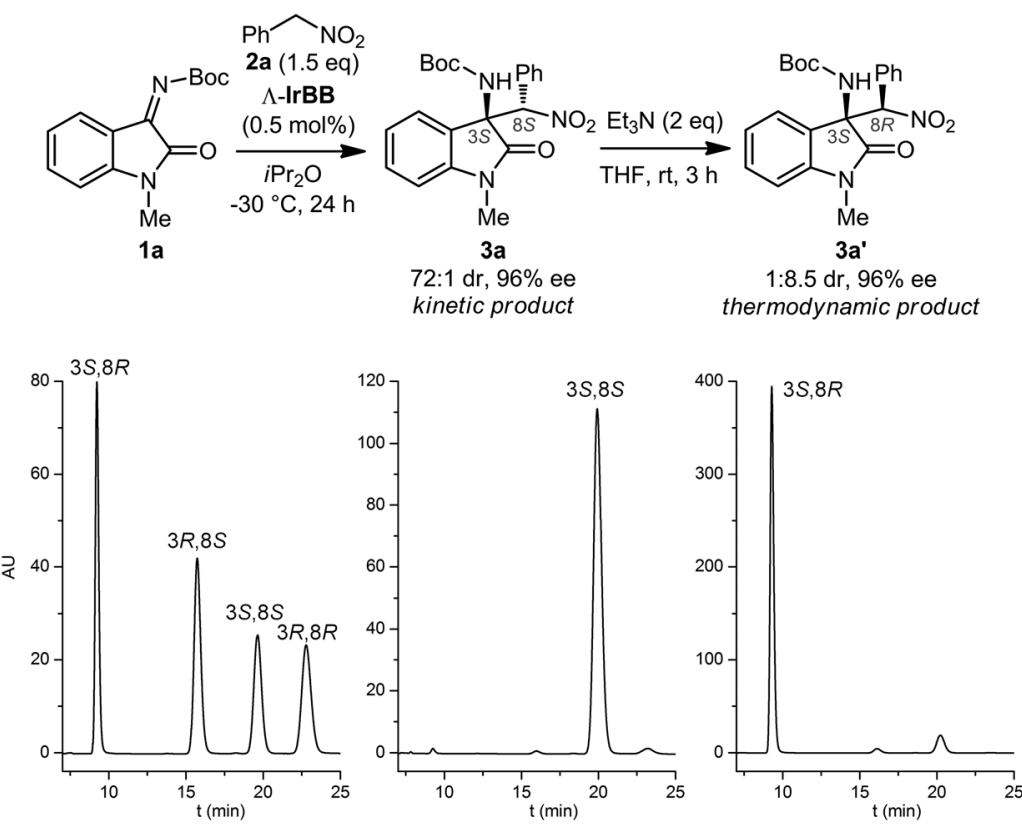

Fig. 2 Initially investigated aza-Henry reaction with an isatin $N$-Boc ketimine substrate. Enantioselectivity of the crude products as determined by HPLC on chiral stationary phase (Daicel Chiralpak IC column, UV detection at $254 \mathrm{~nm}$, mobile phase $=n$-hexane/isopropanol $75: 25$, flow rate $=$ $0.90 \mathrm{~mL} \mathrm{~min}{ }^{-1}$, temperature $=25^{\circ} \mathrm{C}$ ). Shown are HPLC traces of a mixture of isomers (left), the crude kinetic product (middle), and the crude thermodynamic product (right).

formed with high enantioselectivity (96\% ee) and high diastereoselectivity (72:1 dr) (Fig. 2, bottom). Compound 3a could be isolated as a pure single enantiomer (>99\% ee, 138:1 dr) by washing the crude product with a solvent mixture out of toluene and $n$-hexane $(1: 2)$. The compound is prone to epimerization and, in our hands, could not be purified by silica gel chromatography. When we treated the crude 3a $(96 \%$ ee, $72: 1 \mathrm{dr}$ ) with triethylamine ( 2 equiv.) in THF at room temperature, we observed a conversion to the diastereomer $3 \mathbf{a}^{\prime}$ (1: 8.5 dr, 96\% ee) whose absolute and relative configuration were assigned by X-ray crystallography of a brominated derivative (Fig. 3b). 


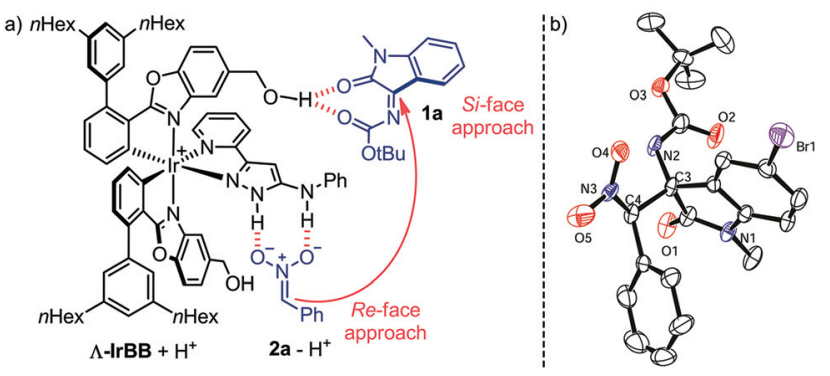

Fig. 3 Plausible mechanism. (a) Proposed hydrogen bonded ternary complex after proton transfer which leads to the kinetic product 3a. (b) Crystal structure of the thermodynamic product $3 \mathbf{k}^{\prime}$ for which the absolute configuration was assigned as $3 S, 8 R$.

Based on these results, a proposed mechanism involves an initial proton transfer from (nitromethyl)benzene $(2 \mathrm{a})\left(\mathrm{p} K_{\mathrm{a}}=\right.$ 12.2 in DMSO) ${ }^{15}$ to the Brønsted base $\Lambda$-IrBB $\left(\mathrm{p} K_{\mathrm{a}} \sim 16\right.$ of protonated $\Lambda$-IrBB in $\mathrm{MeCN}),{ }^{9}$ which allows to form a double hydrogen bond between the aminopyrazole unit of the protonated catalyst and the nitronate. Additional attractive electrostatic forces between the cationic protonated catalyst and the nitronate anion will provide an additional stabilization and are optimized by using a fairly nonpolar solvent. Furthermore, it is plausible to assume that a three center hydrogen bond is established between two carbonyl groups of the isatin $\mathrm{N}$-Boc ketimine and one hydroxy group of the catalyst, providing the ternary complex as shown in Fig. $3 \mathrm{a}^{16}$ We verified the importance of the hydroxy group by using a catalyst devoid of both $\mathrm{CH}_{2} \mathrm{OH}$ groups and we observed only a sluggish catalysis that required an increased catalyst loading to reach a full conversion and provided the product 3a only with a low diastereoand enantioselectivity (see $\mathrm{ESI} \dagger$ for more details). According to our model for the catalysis with $\Lambda$-IrBB, the two substrates are brought into close proximity and preorganized for a Reface/Si-face attack of the nitronate nucleophile to the ketimine electrophile, thereby being consistent with the observed stereochemistry of 3a. This compound apparently constitutes the kinetically favored product and the high acidity of the proton in $\alpha$-position of the nitro group allows a base-catalyzed conversion to the thermodynamically more stable diastereomer $3 \mathbf{a}^{\prime}$.

Finally, we investigated the substrate scope of the reaction between isatin $N$-Boc ketimines and aryl nitromethanes for the formation of the thermodynamically more stable diastereomers $\left(\mathbf{3 a}^{\prime}-\mathbf{t}^{\prime}\right)$. Fig. 4 demonstrates that the reaction tolerates electron donating and electron withdrawing groups within the indole moiety and within the phenyl group of the nitro substrate, and different substituents on the indole nitrogen. Overall, under optimized conditions with a catalyst loading of $0.5 \mathrm{~mol} \%$, excellent yields were observed (92-99\%), high enantioselectivities (90-98\% ee), whereas diastereoselectivities were found to be in the range between $23: 1$ and $8: 1$, which must reflect the relative thermodynamic stabilities of the two diastereomers. It is worth noting that the catalyst loading can even be reduced to $0.25 \mathrm{~mol} \%$ while only slightly affecting the

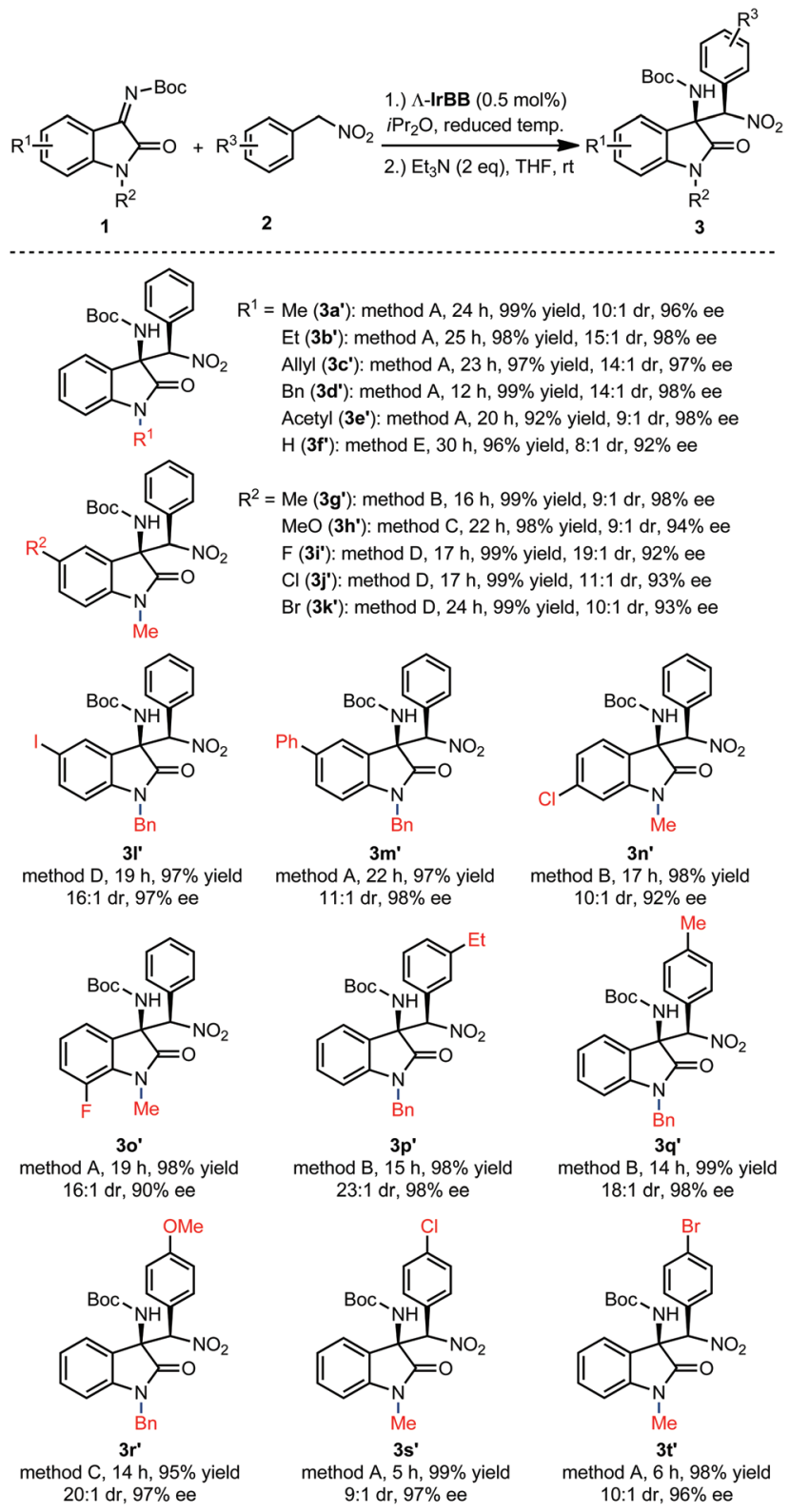

Fig. 4 Scope of the aza-Henry reaction with isatin ketimines catalyzed by $\Lambda$-IrBB. Method A: $-30{ }^{\circ} \mathrm{C}$ at $100 \mathrm{mM}$ imine. Method B: $-20{ }^{\circ} \mathrm{C}$ at $100 \mathrm{mM}$ imine. Method C: $0{ }^{\circ} \mathrm{C}$ at $100 \mathrm{mM}$ imine. Method D: $-40^{\circ} \mathrm{C}$ at $50 \mathrm{mM}$ imine. Method $\mathrm{E}:-10^{\circ} \mathrm{C}$ at $100 \mathrm{mM}$ imine. Shown are isolated yields. Diastereo- and enantioselectivities were determined by HPLC on a chiral stationary phase. 1-Methyl-2-(nitromethyl)benzene and ketimine $1 \mathrm{a}$ with an additional methyl group at the 4-position of the oxindole are not suitable substrates for this reaction, presumably due to a hindrance of hydrogen bond interactions with the catalyst.

stereoselectivity. For example, with a loading of $0.25 \mathrm{~mol} \%$ $\Lambda$-IrBB, the kinetic product 3a was obtained with $96 \%$ ee and $82: 1 \mathrm{dr}$ after an elongated reaction time of $36 \mathrm{~h}$ at $-30{ }^{\circ} \mathrm{C}$, and subsequently converted to the thermodynamic product upon treatment with $\mathrm{Et}_{3} \mathrm{~N}$ to obtain $3 \mathrm{a}^{\prime}$ in a yield of $98 \%$ with $10: 1 \mathrm{dr}$ and $95 \%$ ee. 
In conclusion, we developed a diastereoselective (up to $23: 1 \mathrm{dr}$ ) and highly enantioselective (up to $98 \%$ ee) method to oxindoles bearing a quaternary stereocenter in 3-position by using an aza-Henry reaction between isatin $N$-Boc ketimines and aryl nitromethanes, catalyzed by an inert octahedral biscyclometalated iridium(III) complex which served as a chiral Brønsted base. This work underscores the potential of our metal-templated approach for the design of high performance asymmetric catalysts.

\section{Acknowledgements}

We gratefully acknowledge funding from the National Natural Science Foundation of P. R. China (grant no. 21272192, 21201143, and 21472154) the Program for Changjiang Scholars and Innovative Research Team of P. R. China (PCSIRT), the National Thousand Talents Program of P. R. China, and the 985 Program of the Chemistry and Chemical Engineering disciplines of Xiamen University.

\section{References}

1 For reviews on asymmetric catalytic aza-Henry reactions, see: (a) B. Westermann, Angew. Chem., Int. Ed., 2003, 42, 151-153; (b) E. Marqués-López, P. Merino, T. Tejero and R. P. Herrera, Eur. J. Org. Chem., 2009, 2401-2420; (c) A. Noble and J. C. Anderson, Chem. Rev., 2013, 113, 2887-2939.

2 For enantioselective aza-Henry reactions catalyzed by chiral Brønsted bases, see: (a) T. Okino, S. Nakamura, T. Furukawa and Y. Takemoto, Org. Lett., 2004, 6, 625-627; (b) K. R. Knudsen and K. A. Jørgensen, Org. Biomol. Chem., 2005, 3, 1362-1364; (c) L. Bernardi, F. Fini, R. P. Herrera, A. Ricci and V. Sgarzani, Tetrahedron, 2006, 62, 375-380; (d) M. T. Robak, M. Trincado and J. A. Ellman, J. Am. Chem. Soc., 2007, 129, 15110-15111; (e) Y.-w. Chang, J.-j. Yang, J.-n. Dang and Y.-x. Xue, Synlett, 2007, 2283-2285; (f) C. Wang, Z. Zhou and C. Tang, Org. Lett., 2008, 10, 1707-1710; $(g)$ C. Rampalakos and W. D. Wulff, Adv. Synth. Catal., 2008, 350, 1785-1790; (h) C. Rabalakos and W. D. Wulff, J. Am. Chem. Soc., 2008, 130, 13524-13525; (i) B. Han, Q.-P. Liu, R. Li, X. Tian, X.-F. Xiong, J.-G. Deng and Y.-C. Chen, Chem. - Eur. J., 2008, 14, 8094-8097; (j) K. Takada and K. Nagasawa, Adv. Synth. Catal., 2009, 351, 345-347; ( $k$ ) X. Jiang, Y. Zhang, L. Wu, G. Zhang, X. Liu, H. Zhang, D. Fu and R. Wang, Adv. Synth. Catal., 2009, 351, 2096-2100; (l) T. A. Davis, J. C. Wilt and J. N. Johnston, J. Am. Chem. Soc., 2010, 132, 2880-2882; (m) Z.-X. Jia, Y.-C. Luo and P.-F. Xu, Org. Lett., 2011, 13, 832-835; (n) T. A. Davis and J. N. Johnston, Chem. Sci., 2011, 2, 1076-1079; (o) D. Uraguchi, K. Oyaizu and T. Ooi, Chem. - Eur. J., 2012, 18, 8306-8309; (p) H. Li, X. Zhang, X. Shi, N. Ji, W. He, S. Zhang and B. Zhang, Adv. Synth. Catal., 2012, 354, 2264-2274; (q) N. R. Amarasinghe,
P. Turner and M. H. Todd, Adv. Synth. Catal., 2012, 354, 2954-2958; (r) B. Zheng, W. Hou and Y. Peng, ChemCatChem, 2014, 6, 2527-2530.

3 For bifunctional asymmetric organocatalysis, see: (a) Y. Takemoto, Org. Biomol. Chem., 2005, 3, 4299-4306; (b) S. J. Connon, Chem. - Eur. J., 2006, 12, 5418-5427; (c) A. G. Doyle and E. N. Jacobsen, Chem. Rev., 2007, 107, 5713-5743; (d) X. Yu and W. Wang, Chem. - Asian J., 2008, 3, 516-532; (e) D. H. Paull, C. J. Abraham, M. T. Scerba, E. Alden-Danforth and T. Lectka, Acc. Chem. Res., 2008, 41, 655-663; $(f)$ T. Kano and K. Maruoka, Chem. Commun., 2008, 5465-5473; (g) X. Liu, L. Lin and X. Feng, Chem. Commun., 2009, 6145-6158; (h) L.-Q. Lu, X.-L. An, J.-R. Chen and W.-J. Xiao, Synlett, 2012, 490-508; (i) O. V. Serdyuk, C. M. Heckel and S. B. Tsogoeva, Org. Biomol. Chem., 2013, 11, 7051-7071; $(j)$ X. Fang and C.-J. Wang, Chem. Commun., 2014, 51, 1185-1197.

4 For metal-templated asymmetric catalysis from our group, see: (a) L.-A. Chen, W. Xu, B. Huang, J. Ma, L. Wang, J. Xi, K. Harms, L. Gong and E. Meggers, J. Am. Chem. Soc., 2013, 135, 10598-10601; (b) L.-A. Chen, X. Tang, J. Xi, W. Xu, L. Gong and E. Meggers, Angew. Chem., Int. Ed., 2013, 52, 14021-14025; (c) H. Huo, C. Fu, C. Wang, K. Harms and E. Meggers, Chem. Commun., 2014, 50, 10409-10411.

5 For related chiral-at-metal octahedral iridium(III) and rhodium(III) catalysts from our group, see: (a) H. Huo, C. Fu, K. Harms and E. Meggers, J. Am. Chem. Soc., 2014, 136, 2990-2993; (b) H. Huo, X. Shen, C. Wang, L. Zhang, P. Röse, L.-A. Chen, K. Harms, M. Marsch, G. Hilt and E. Meggers, Nature, 2014, 515, 100-103; (c) C. Wang, L.-A. Chen, H. Huo, X. Shen, K. Harms, L. Gong and E. Meggers, Chem. Sci., 2015, 5, 1093-1100; (d) C. Wang, Y. Zheng, H. Huo, P. Röse, L. Zhang, K. Harms, G. Hilt and E. Meggers, Chem. - Eur. J., 2015, 21, 7355-7359.

6 For the design of metal-templated asymmetric catalysts from other groups, see: (a) Y. N. Belokon, A. G. Bulychev, V. I. Maleev, M. North, I. L. Malfanov and N. S. Ikonnikov, Mendeleev Commun., 2004, 14, 249-250; (b) Y. N. Belokon, V. I. Maleev, D. A. Kataev, I. L. Mal'fanov, A. G. Bulychev, M. A. Moskalenko, T. F. Saveleva, T. V. Skrupskaya, K. A. Lyssenko, I. A. Godovikov and M. North, Tetrahedron: Asymmetry, 2008, 19, 822-831; (c) C. Ganzmann and J. A. Gladysz, Chem. - Eur. J., 2008, 14, 5397-5400; (d) N. Kurono, K. Arai, M. Uemura and T. Ohkuma, Angew. Chem., Int. Ed., 2008, 47, 6643-6646; (e) N. Kurono, N. Nii, Y. Sakaguchi, M. Uemura and T. Ohkuma, Angew. Chem., Int. Ed., 2011, 50, 5541-5544; (f) Y. N. Belokon, V. I. Maleev, M. North, V. A. Larionov, T. F. Savel'yeva, A. Nijland and Y. V. Nelyubina, ACS Catal., 2013, 3, 19511955; (g) V. I. Maleev, M. North, V. A. Larionov, I. V. Fedyanin, T. F. Savel'yeva, M. A. Moscalenko, A. F. Smolyakov and Y. N. Belokon, Adv. Synth. Catal., 2014, 356, 1803-1810.

7 For reviews covering chiral-at-metal complexes in catalysis, see: (a) H. Brunner, Angew. Chem., Int. Ed., 1999, 38, 11941208; (b) P. Knight and P. Scott, Coord. Chem. Rev., 2003, 
242, 125-143; (c) M. Fontecave, O. Hamelin and S. Ménage, Top. Organomet. Chem., 2005, 15, 271-288; (d) E. B. Bauer, Chem. Soc. Rev., 2012, 41, 3153-3167; (e) L. Gong, L.-A. Chen and E. Meggers, Angew. Chem., Int. Ed., 2014, 53, 10868-10874; (f) Z.-Y. Cao, W. D. G. Brittain, J. S. Fossey and F. Zhou, Catal. Sci. Technol., 2015, DOI: 10.1039/ C5CY00182J.

8 For different aspects of metal-centered chirality, see: (a) U. Knof and A. von Zelewsky, Angew. Chem., Int. Ed., 1999, 38, 302-322; (b) H. Brunner, Angew. Chem., Int. Ed., 1999, 38, 1194-1208; (c) P. D. Knight and P. Scott, Coord. Chem. Rev., 2003, 242, 125-143; (d) M. Fontecave, O. Hamelin and S. Ménage, Top. Organomet. Chem., 2005, 15, 271-288; (e) H. Amouri and M. Gruselle, Chirality in Transition Metal Chemistry, Wiley, Chichester, UK, 2008; (f) J. Crassous, Chem. Soc. Rev., 2009, 38, 830-845; (g) E. Meggers, Eur. J. Inorg. Chem., 2011, 2911-2926;

(h) J. Crassous, Chem. Commun., 2012, 48, 9684-9692; (i) E. C. Constable, Chem. Soc. Rev., 2013, 42, 1637-1651.

9 J. Ma, X. Ding, Y. Hu, Y. Huang, L. Gong and E. Meggers, Nat. Commun., 2014, 5, 4531.

10 X. Ding, H. Lin, L. Gong and E. Meggers, Asian J. Org. Chem., 2015, 4, 434-437.

11 For asymmetric aza-Henry reactions with ketimines, see: (a) C. Tan, X. Liu, L. Wang, J. Wang and X. Feng, Org. Lett., 2008, 10, 5305-5308; (b) H. Xie, Y. Zhang, S. Zhang, X. Chen and W. Wang, Angew. Chem., Int. Ed., 2011, 50, 11773-11776; (c) A. Parra, R. Alfaro, L. Marzo, A. MorenoCarrasco, J. L. García Ruano and J. Alemán, Chem. Commun., 2012, 48, 9759-9761; (d) M. G. Núñez, A. J. M. Farley and D. J. Dixon, J. Am. Chem. Soc., 2013, 135, 16348-16351.

12 For asymmetric aza-Henry reactions with isatin ketimines, see: (a) Y.-H. Wang, Y.-L. Liu, Z.-Y. Cao and J. Zhou, Asian J. Org. Chem., 2014, 3, 429-432; (b) T. Arai, E. Matsumura and H. Masu, Org. Lett., 2014, 16, 2768-2771; (c) M. Holmquist, G. Blay and J. R. Pedro, Chem. Commun., 2014, 50, 9309-9312; (d) B. Fang, X. Liu,
J. Zhao, Y. Tang, L. Lin and X. Feng, J. Org. Chem., 2015, 80, 3332-3338.

13 For reviews on the asymmetric synthesis of oxindoles with quaternary stereocenter at the 3-position: (a) C. V. Galliford and K. A. Scheidt, Angew. Chem., Int. Ed., 2007, 46, 87488758; (b) F. Zhou, Y.-L. Liu and J. Zhou, Adv. Synth. Catal., 2010, 352, 1381-1407; (c) N. R. Ball-Jones, J. J. Badillo and A. K. Franz, Org. Biomol. Chem., 2012, 10, 5165-5181; (d) A. Kumar and S. S. Chimni, RSC Adv., 2012, 2, 97489762; (e) S. Mohammadi, R. Heiran, R. P. Herrera and E. Marqués-López, ChemCatChem, 2013, 5, 2131-2148.

14 Examples of bioactive oxindoles with quaternary stereocenter at the 3-position: (a) M. Ochi, K. Kawasaki, H. Kataoka, Y. Uchio and H. Nishi, Biochem. Biophys. Res. Commun., 2001, 283, 1118-1123; (b) M. Suchý, P. Kutschy, K. Monde, H. Goto, N. Harada, M. Takasugi, M. Dzurilla and E. Balentová, J. Org. Chem., 2001, 66, 3940-3947; (c) K. Monde, T. Taniguchi, N. Miura, S.-I. Nishimura, N. Harada, R. K. Dukor and L. A. Nafie, Tetrahedron Lett., 2003, 44, 6017-6020; (d) K. Ding, Y. Lu, Z. NikolovskaColeska, S. Qiu, Y. Ding, W. Gao, J. Stuckey, K. Krajewski, P. P. Roller, Y. Tomita, et al., J. Am. Chem. Soc., 2005, 127, 10130-10131; (e) M. Rottmann, C. McNamara, B. K. S. Yeung, M. C. S. Lee, B. Zou, B. Russell, P. Seitz, D. M. Plouffe, N. V. Dharia, J. Tan, S. B. Cohen, K. R. Spencer, G. E. Gonzalez-Paez, S. B. Lakshminarayana, A. Goh, R. Suwanarusk, T. Jegla, E. K. Schmitt, H.-P. Beck, R. Brun, F. Nosten, L. Renia, V. Dartois, T. H. Keller, D. A. Fidock, E. A. Winzeler and T. T. Diagana, Science, 2010, 329, 1175-1180; $(f)$ A. P. Antonchick, C. GerdingReimers, M. Catarinella, M. Schürmann, H. Preut, S. Ziegler, D. Rauh and H. Waldmann, Nat. Chem., 2010, 2, 735-740.

15 F. G. Bordwell, J. E. Bares, J. E. Bartmess, G. J. McCollum, M. van der Puy, N. R. Vanier and W. S. Matthews, J. Org. Chem., 1977, 42, 321-325.

16 A crystal structure of ketimine $\mathbf{1 k}$ confirms the shown synconfiguration at the imine. See ESI $\uparrow$ for details. 